\title{
Oksana Kozhemiakina
}

http://orcid.org/0000-0002-7196-4857

Państwowy Technologiczny Uniwersytet w Czerkasach (Ukraina)

o.kozhemiakina@chdtu.edu.ua

DOI: $10.35765 /$ pk.2021.3403.08

\section{Komunikatywne podstawy dyskursu genderowego}

\section{STRESZCZENIE}

W artykule przeprowadzono analizę tendencji rozwoju dyskursu genderowego w kontekście jego komunikatywnych podstaw i strategii. Wzięto pod uwagę wewnętrzne i zewnętrzne determinanty komunikatywnych interakcji odpowiednio do ogólnie przyjętych modeli zachowania społeczno-kulturowego. W tekście zwrócono uwagę na kształtowanie nowego aksjologicznego pola współczesnego naukowego dyskursu, uwzględniającego problem nierówności oraz dychotomii genderowej, a także sugerowanej przez autorkę potrzeby sprostania tzw. monologicznemu modelowi męskiej reprezentacji świata i aktualizacji żeńskiej podmiotowości w utwierdzeniu dialogicznego modelu działania komunikatywnego.

SŁOWA KLUCZE: gender, dyskurs, działanie komunikatywne, kobiecość, męskość, troska, zaufanie

\section{ABSTRACT}

\section{Communicative Foundations of Gender Discourse}

The analysis of trends in the development of gender discourse in the context of determining its communicative foundations and strategies, taking into account the internal and external determinations of communicative interactions in accordance with established models of sociocultural behavior. Attention is drawn to the formation of a new value field of modern scientific discourse, with a tangible problematization of issues of gender inequality and gender dichotomy, as well as the need to overcome the monologue model of male representation of the world and actualize female subjectivity in approving the dialogical model of communicative action.

KEYWORD S : gender, discourse, communicative action, femininity, masculinity, care, trust 
Współczesna problematyka genderowa, jako interdyscyplinarny paradygmat kompleksowego badania psychologicznych, społecznych i kulturowych cech żeńskiego i męskiego dyskursu, demonstruje istotne zmiany w rozumieniu genderowego podejścia w kontekście przezwyciężania problemów nierówności genderowej oraz genderowej dychotomii. Kategoria gender, która gwałtownie weszła do humanistyki w drugiej połowie $\mathrm{XX}$ w., staje się jednym $\mathrm{z}$ wiodących przejawów formowania nowego pola aksjologicznego współczesnego dyskursu naukowego. Kategoria ta problematyzuje kwestię pluralizmu, dialogizmu, policentryczności, odmiennego rozumienia podmiotowości oraz inaczej konstruowanej tożsamości. Sprzyja to ideologicznemu założeniu o istnieniu monologicznej postawy męskiego światopoglądu, a także upowszechnieniu praktyk wzmożonej uwagi ku podmiotowym reprezentacjom płci, emancypacji spod monopolu męskich ideałów, odrzuceniu budowania hierarchicznych relacji między mężczyzną a kobietą. Z biegiem czasu gender wszedł do analitycznej metodologii badania systemu relacji społecznych, zaś pole kategorialne gender uzyskuje zrównoważony charakter, otwierając się na wszechstronne badania tego, co żeńskie, i tego, co męskie, m.in. społeczno-kulturowych podstaw żeńskiego i męskiego dyskursu, narratywnych społecznych i kulturowych oczekiwań, podmiotowości genderowej, aktywności społecznych oraz postaw stereotypowych.

Teoretyczne uzasadnienie koncepcji gender we współczesnej nauce (historii, psychologii, filozofii, socjologii, lingwistyce itd.) dokonało się za sprawą idei Georges'a Kelly'ego (1905-1967), Joan Wallach Scott (ur. 1941), Judith Butler (ur. 1956), Michela Foucaulta (1926-1984), Michelle Rosaldo (1944-1981), Elizabeth Janeway (1913-2005), Yvonne Hirdman (ur. 1943), Robin Lakoff (ur. 1942) i innych, którzy określili zakres problemowy badań genderowych, dokonali periodyzacji historii genderowej, opracowali aparat pojęciowy oraz położyli podwaliny pod dalsze badania tego obszaru. Scott zaproponowała, aby rozumieć podejście genderowe jako myślenie dychotomiczne, zakładając możliwość rozpatrywania konkretnych wydarzeń oczyma zarówno kobiety, jak i mężczyzny, wskazując, z różnych punktów widzenia, na podobieństwa i różnice, na to, co jest w nich uniwersalne i wyjątkowe (Scott, 1986). Gender jest rozwijany przez Scott w perspektywie społeczno-kulturowej, konstytuującej tożsamość jako sposób określania i wyrażania społecznej organizacji relacji między płciami, w tym władczych struktur dominacji i podporządkowania, wyznaczając warunki kulturowej interakcji z możliwością nowego ujęcia, odrzucenia, sprzeciwu. Badając szerokie konteksty wykorzystania problematyki genderowej, w tym też ujawniając mechanizmy powstania pozaczasowej przestrzeni w binarnej genderowej reprezentacji, badaczka proponuje, aby wprowadzić cztery główne bloki dla „optyki genderowej” 
w procesie zmian społecznych: 1) obrazowo-symboliczne przedstawienie mężczyzn i kobiet w kulturze, 2) normatywne podstawy interakcji genderowej, 3) polityka genderowa w aspekcie funkcjonowania instytucji i organizacji społecznych oraz 4) subiektywna tożsamość i problemy z wyrażaniem siebie, co razem wyznacza swoistość dyskursu gender oraz form jego legitymizacji w każdym z zaznaczonych podsystemów.

Uznając ogólne różnice istniejące między mężczyznami i kobietami, w tym też różnice w kulturach temporalnych, Bryson dokonuje konceptualizacji tych różnic nie w terminach wrodzonych sposobów zachowania, ale jako odzwierciedlenie ich współczesnych ról społecznych, przytaczając twierdzenie Simone de Beauvoir o tym, że kobiety kobietami się nie rodzą, ale się nimi stają (Bryson, 2011, s. 68-69). Dlatego w problematyce gender szczególnie ostro stawiane są pytania o tożsamość genderową i struktury władczych dominacji (m.in. nierównomiernej dystrybucji władzy i możliwości) w różnych sferach - politycznej, ekonomicznej, prawnej, moralnej, osobowej, zawodowej itp., co znajduje odzwierciedlenie i późniejsze utrwalenie w komunikacyjnych strategiach dominującego dyskursu. $\mathrm{W}$ ten sposób gender staje się jedną ze znaczących koncepcji interakcji komunikacyjnej, przenikając do praktyk codzienności w postaci pewnych kompleksów interakcji zorientowanych społecznie.

Lingwistyczna perspektywa problematyki genderowej uwzględnia przede wszystkim skonstruowane w języku i zaszczepione w świadomości utrwalone obrazy i charakterystyki konkretnych ról, które wyznaczają wewnętrzne i zewnętrzne determinanty komunikacyjnych interakcji zgodnie z utrwalonymi modelami zachowań społeczno-kulturowych. Szczególnie interesujące są tzw. niewerbalne środki komunikacji, które stanowią pole badań bloku paralingwistycznego. One ujawniają skuteczność tego, co nie jest werbalne w przejawach modulacji głosu, ruchach kinestetycznych, postawie itp., towarzysząc, zastępując, uzupełniając wyrażenia językowe, zapewniając jednocześnie znacznie większą informatywność i oczywistość sensów aniżeli same te werbalne komunikaty.

Według Foucaulta, praktyki zachowań językowych opierają się na dwóch odmianach dyskursu - językowej (werbalnej) i pozajęzykowej (niewerbalnej). Dyskurs, jako rozumowanie w sensie praktyk werbalnych i niewerbalnych zachowań, obejmuje szeroki wachlarz tekstów, idei, które są w pewien sposób wypowiadane, bronione, dyskutowane, w całości generując intencje wielości, niejednostkowości (Foucault, 2004). Dyskurs stanowi zatem system praktyk językowych, wpływając na kształtowanie się wyobrażeń o przedmiocie języka; zawsze jest nim mowa zainteresowana, dowolne skojarzenie faktów i fantazji, co właśnie wyznacza pewne konstrukty społeczne (Foucault, 1995). Do dyskursu niewerbalnego Foucault odnosi, oprócz znaków, symboli i innych nieujętych w słowa wyrażeń, też 
swoistą pozajęzykową rzeczywistość - władzę, ciało, działanie, co właśnie staje się wyrazowym systemem reprezentacji środków wyrażania siebie i dominacji, ustalając nierównomierne pozycjonowanie komunikacji genderowych w licznych społecznych praktykach i instytucjach, całkowicie nadając porządek systemowi relacji.

W badaniu pytań na temat Innego (Other jako kategoria fenomenologiczna) w genderowych aspektach podmiotowości filozoficznej Luce Irigaray (ur. 1930) zastanawia się nad przezwyciężeniem niezmiennej tradycji historycznej podstawowego modelu człowieka jako idealnie męskiego w kontekście potrzeby ukształtowania żeńskiej podmiotowości, innej reprezentacji odmienności, uwalniając podmiot żeński od świata męskiego. Jednym z ważnych wymiarów kształtowania się podmiotu żeńskiego jest wyjście z genealogicznej władzy tego jedynego światopoglądu, przywrócenie żeńskich genealogii i wyposażenie kobiety w język, obrazowość oraz wyobrażenia odpowiadające nowej podmiotowości (Irigaray, 1997, s. 50-53). Tradycja utwierdzała obowiązek kobiety, aby być opiekunką, akceptować zobowiązania miłości i troski, pomimo wszystkich problemów, kierując odpowiednie reprezentacje ludzkiej tożsamości.

Znalazło to odzwierciedlenie w szczególnym żeńskim języku, języku zatroskania się o Innego, posłudze wobec Innego, pokory i potrzeby uzyskania przyzwolenia, co ma oczywistą wyrazistość w genderowych cechach niewerbalnych komunikacji. Artykulacja gender w języku była badana w pracach wspomnianej Robin Lakoff, a także w pracach Deborah Tannen (ur. 1945), Janet Holmes (ur. 1947), Kiry Hall (ur. 1966) i wielu innych, w których ustala się wyraźny wpływ języka na genderową binarność i władcze dominacje patriarchalnej struktury języka (Hall, 1995). Tak np. Mary Ritchie Key (ur. 1924) określa męski język jako „język wyjaśnień”, natomiast język żeński - jako „język usprawiedliwień” (Key, 1975, s. 147).

Odpowiednio przejawia się tė̇ paralingwistyczna męskość jako wcielenie siły, agresywności i rozumu, zaś kobiecość - jako demonstracja słabości, pokory i zmysłowej wrażliwości. Niewerbalne wymiary kobiecości w swej postaci tradycyjnej świadczą o społeczno-kulturowych determinantach uległości i wyobcowania żeńskiego jako takiego pod wpływem symboliki zrytualizowanego męskiego panowania. Dosyć pokaźne w danym kontekście są badania genderowych aspektów społeczno-psychologicznej proksemiki, które demonstrują wyraźny wpływ mentalności genderowej na dominujące postawy ciała, zakres przestrzeni osobowej, jej emocjonalne wypełnienie, typowe reakcje na przekroczenie granic tejże przestrzeni (Sommer, 1969).

Według obserwacji Irigaray, specyfika kobiecej tożsamości domaga się zbudowania wyjątkowej relacji z Innym, zwracającej szczególną uwagę na niego, co właśnie zadecydowało o podmiotowo-podmiotowym ukierunkowaniu działania komunikatywnego oraz intersubiektywnych 
podstawach społecznego współdziałania. Akt wzajemnego uznania Innego jako Innego jest przez badaczkę postrzegany jako „zdecydowany filozoficzny i polityczny gest” (Irigaray, 1997, s. 59), który staje się niezbędnym fundamentem nowej ontologii, etyki i polityki. Dyskurs genderowy w takim kontekście jest zorganizowany na zasadach dialogu, z priorytetami wzajemności, otwartości, poszukiwań optymalnych form uzgodnienia i empatycznego zrozumienia.

Można więc powiedzieć, że mentalność genderowa w przestrzeni niewerbalnej przybiera rozmaite subiektywne konfiguracje i odmienne podmiotowe strategie (m.in. męskiej monologiczności i kobiecej dialogiczności), wykazując się genderowo-komunikatywnym powiązaniem z kwestiami stanowienia żeńskiej subiektywności. Wpływa ona też na dynamikę rozwoju i sposoby przezwyciężenia dominacji męskiego dyskursu, wdrażając praktyki absolutnego respektowania odmienności Innego/Innej oraz komunikatywnego konstruowania ich transcendentności.

Należy też zwrócić uwagę, że dyskurs kobiecy nigdy nie był konstytutywny w historii filozofii, aktualizując m.in. problematykę okluzji kobiet w filozofii, konieczności poszerzania mentalnych granic dyskursu genderowego, a także bezpośrednio filozoficznej legitymacji problematyki genderowej. Filozoficzna rola kobiety tkwiła przede wszystkim w nieczęsto pojawiających się wątkach towarzyszki, muzy, współrozmówcy, czasem nawet uczennicy, ale zawsze gdzieś na drugim planie. Zarówno personalia filozoficzne, jak też główne konceptualne personaże reprezentowały męski pogląd na świat i na miejsce człowieka w tym świecie. Odpowiadając na pytanie, czy filozof jako taki jest naznaczony cechą płciową, Françoise Colin (1928-2012) mówi o jednostronności filozofii jako męskiej (Colin, 2007, s. 371). Za sprawą odizolowania implikowanego przez panujący model społeczny kobiety były odsunięte zarówno od politycznego, jak też filozoficznego słowa, odczuwając nawet w obecnych warunkach specyficzną „obronną opozycję” przestrzeni filozoficznej wobec pojawienia się kobiet. W omawianym badaniu podkreśla się, że pomimo aktywnej pozycji kobiet w różnych sferach społecznych ich dyskurs nie stał się konstytutywnym wzorcem dla sfery obywatelskiego i realnie funkcjonującego myślenia. Różnice genderowe są nadal opisywane jako różnice między kobietami i mężczyznami, a dokładniej - w tradycyjnych kategoriach, tego, co jest szczególne (żeńskie) i uniwersalne (męskie), wciąż utwierdzających logocentryczne pozycje męskiej dominacji.

Jednocześnie swego rodzaju konceptualne przeformułowanie dyskursu genderowego w filozoficznej refleksji tego, co jest uniwersalne, odnajdujemy w analizie komunikacyjnych podstaw moralnego działania. Taka analiza odzwierciedla emancypacyjne intencje poznawczego zainteresowania w transformacjach subiektywnego sensu i specyfiki orientacji 
na Innego/Inną. W tym kontekście szczególnie przydatna staje się koncepcja działania komunikacyjnego Jürgena Habermasa (ur. 1929), zakładająca konceptualizację dyskursu jako idealnej sytuacji komunikacyjnej, możliwej w postaci praktyk dyskursywnego omawiania problemów. Zgodnie $\mathrm{z}$ terminologią Habermasa, celowo-racjonalna relacja, jako relacja podmiotowo-przedmiotowa, zmierza do opanowania przedmiotu, przejęcia kontroli nad nim i jest działaniem strategicznym. Natomiast relacja aksjologiczno-racjonalna jest relacją podmiotowo-podmiotową i wiąże się z działaniem komunikatywnym. Przy tym ważne aspekty dyskursu genderowego, znaczące dla równości szans w trakcie korzystania z subiektywnej wolności w działaniach, muszą być wyjaśnione „w ramach polityki publicznej, dokładniej rzecz biorąc - w publicznym sporze na temat odpowiedniej interpretacji potrzeb” (Habermas, 2006, s. 293).

Porównując ze sobą komunikacyjne i strategiczne działania, Habermas zwraca uwagę na efekt uzgodnienia interakcji, skierowanych na rozwiązanie problemu skoordynowanych działań wielu uczestników społecznego współdziałania. W podobnej interakcji działania Alter w przestrzeniach możliwości wyboru dołączają się ku działaniom Ego (Habermas, 2011, s. 53-54). Genderowa problematyka zaufania jako strategicznego i komunikatywnego działania staje się najbardziej wyraźna właśnie w kontekście sprostania celowo-racjonalnemu nastawieniu na realizację własnych planów. Podobne sprostanie pozwala dostrzec współzależność, potrzebę obecności innego i uzależnienia od jego działań. Na to właśnie wskazuje analiza zaufania jako zasobu integracji społecznej i uzgodnienia sensów. Podobna integracja i uzgodnienie są oparte na racjonalnie umotywowanych postawach wzajemnego zrozumienia i manifestacjach zorientowanej komunikatywnie zgody. Dlatego telos (cel) genderowego porozumienia prowokuje komunikatywnie aktywne podmioty do zmiany perspektyw: od nastawionej na sukces obiektywistycznej postawy osiągnięcia czegoś do performatywnej postawy zgody (Habermas, 2011, s. 105-106).

Archetypem działania celowo-racjonalnego (z leżącą u jego podstaw relacją podmiot-przedmiot) jest koncepcja polowania. W takim działaniu są realizowane takie zasady jak podporządkowanie-uległość oraz rozkaz-posłuszeństwo. Przyczynia się to do określenia archetypu polowania (jako realizacji działania strategicznego) jako rodzaju racjonalności męskiej, podczas gdy paradygmat relacji podmiot-podmiot obecny w działaniu komunikatywnym jest rodzajem żeńskiej racjonalności, bazującej nie na opanowaniu przedmiotu, ale na relacji z Innym jako podmiotem, który potrzebuje troski, co jest przesłanką do powstania relacji wzajemności. W ten sposób aktualizuje się samo znaczenie tego rodzaju komunikatywnej relacji i działalności, uzyskiwane poprzez konkretne społeczne współdziałanie. 
Według Annette C. Baier system etyczny kobiet różni się nieco od odpowiedniego męskiego systemu. Odpowiednio, historia filozofii moralnej napisana przez mężczyzn nie uwzględnia tych genderowych różnic. Opis istotowych podstaw moralnych działań odwołujący się tylko do rozumu, który dominuje w męskim punkcie widzenia, jest niewystarczający. W kwestiach sądów aksjologicznych należy również uwzględniać właściwe dla żeńskiego punktu widzenia „poczucie moralne”, które właśnie wyznacza jego status genderowy w filozofii działania i w myśleniu moralnym. Ujawniając determinanty męskich i żeńskich motywów w ewolucji teorii moralnych, Baier określa jako męskie moralne motywy etos zobowiązania i sprawiedliwości, zaś etos miłości i troski postrzega ona jako motywy żeńskie (Baier, 2009).

Jako alternatywę, strategię ich organicznej komplementarności, badaczka proponuje etos zaufania, który niweluje przeciwstawienie pomiędzy zobowiązaniami a troską, między rozumem a uczuciami, dostrzegając w zaufaniu sposób na harmonizację sprawiedliwości i troski. Język zaufania, jako przejaw działania komunikatywnego, staje się środkiem wyrażania aksjologicznego uznania Innego/Innej, z góry determinując interpretację rzeczywistości w kategoriach aktywnego aksjologiczno-racjonalnego współdziałania, w przeciwieństwie do instrumentalnych koncepcji dominacji, siły, manipulacji, kategoryzacji. Ogólnie Baier, odwołując się do idei refleksyjnych wrażeń teorii świadomości moralnej Hume’a, nalega na konceptualizację zaufania jako zdolnej do samoregulacji społecznej i moralnej cnoty. Tak rozumiane zaufanie zawiera w sobie uczucia, przekonania i zamiary, których ukierunkowanie nie jest ostatecznie znane, co właśnie czyni zaufanie ryzykownym i ułomnym.

Moralnym fundamentem kultury zaufania, jako działania skierowanego na dobro, jest etyka odpowiedzialności. Podobna etyka bazuje na wspólnie wypracowanych normach intersubiektywnych, motywacyjnie i orientacyjnie określających dobrowolnie wzajemnie uznawane standardy modalnego i obligatoryjnego działania w obszarze publicznym. W sensie genderowej samorealizacji etos zaufania sprzyja minimalizacji destrukcyjnego potencjału konfliktów społecznych, inicjując poszukiwanie horyzontów rozumienia, utwierdzanie norm dobra moralnego, wzajemnego uznania oraz etosu troski. W ten sposób, to właśnie zaufanie może zapewnić życiowo ważne powiązania pomiędzy tradycyjnie męskimi wyobrażeniami na temat racjonalnych obowiązków a tradycyjnie żeńską etyką miłości i troski. Zaufanie stanowi fundamentalną podstawę współzależności oraz interakcji w relacjach społecznych, aktualizując konieczność opracowania i wdrażania modeli etyki troski, partnerstwa oraz wzajemnej pomocy.

Troska zakłada także pewien genderowy kontekst świadomości temporalnej: dochodzi do konfrontacji dominującego w społeczeństwie czasu 
monochromatycznego (odpowiadającego pierwiastkowi męskiemu) $\mathrm{z}$ realizującym pełnię troski i uwagi ku relacjom czasem polichromatycznym (odpowiadającym pierwiastkowi żeńskiemu). Taka postawa przyczynia się do traktowania żeńskich motywów działania komunikatywnego jako podstawy uogólnionej etycznej postawy wobec ludzi w ogóle. Aktywizuje ona bowiem projekty partycypacji, wspólnych inicjatyw rozwojowych, interakcji, poszerzania perspektyw i możliwości dyskursu genderowego. Dlatego w potencjalnie konfliktowych warunkach, zwłaszcza w sytuacji zaostrzenia się globalnych problemów naszych czasów, przesłanką do normalnego rozwoju społeczeństwa, w tym także w kontekście racjonalności technicznej, powinna się stać właśnie żeńska komunikatywna racjonalizacja, która będzie sprzyjać utwierdzeniu etosu zaufania i wzajemnego zrozumienia jako wartości ogólnoludzkich. Dzięki strukturom komunikatywnej racjonalności dyskurs genderowy szybko wkracza zatem w przestrzeń myśli i działania, publicznych i prywatnych praktyk, problematyzując m.in. filozoficzną refleksję na temat komunikatywnych podstaw interakcji społecznej.

\section{BIBLIOGRAFIA}

Baier, A.C. (2009). Reflections on How We Live. New York: Oxford University Press.

Bryson, V. (2011). Gender i politika vremeni: feminist skaya teoriya i souremennyye debaty. Tłum. A. Jakubin. Kijów: Tsentr uchebnoy literatury. Wydanie oryginalne: Bryson, V. (2007). Gender and the politics of time. Feminist Theory and Contemporary debates. Bristol: Policy Press.

Collen, F. (2007). Zabuttya odnogo starogo f losofs'kogo pitanya. W: O. Choma (red.), Pro rivnist' statey. Zbirnik. Kijów: A'.'terpres, 368-384. Wydanie oryginalne: Entretien avec Françoise Collin. Philosophe et intellectuelle féministe. W: Michel de Manassein (dir.). (1995). De l'egalite des sexes. Paris: CHDP.

Foucault, M. (1995). Govoryashchiy pol (Seksual'nost' v sisteme mikrofiziki vlasti). Sovremennaya filosofiya, nr 1, 110-172. Foucault, M. (1995). Talking gender (Sexuality in the microphysics system of power) / Modern philosophy, nr 1, 110-172.

Foucault, M. (2004). Arkheologiya znaniya. Sankt Petersburg: Gumanitarnaya akademiya. Wydanie polskie: Foucault, M. (1977). Archeologia wiedzy. Warszawa: PIW.

Habermas, J. (2006). Zaluchennya nshogo. Studï̈ z politichnoï teorï̈, tłum. A. Dachnij. Lwów: Astrolyabiya. Wydanie oryginalne: Habermas, J. (1999). Die Einbeziehung des Anderen: Studien zur politischen Theorie. Frankfurt am Main: Suhrkamp Verlag. 
Habermas, J. (2011). Postmetaf zichne mislennya, tłum. W. Kuplin. Kijów: Dukh i Litera. Wydanie oryginalne: Habermas, J. (1988). Nachmetaphysisches Denken: Philosophische Aufsatze. Frankfurt am Main: Suhrkamp Verlag.

Hall, K. (1995). Lip-service on the fantasy lines. W: K. Hall i M. Bucholtz (red.), Gender Articulated: Language and the Socially Constructed Self. New York: Routledge, 183-216.

Irigaray, L. (2007). Pitanya pro nshogo. W: O. Choma (red.), Pro r un st'statey. Zb rnik. Kijów: Al'terpres, 47-59. Wydanie oryginalne: Irigaray, L. (1995). Question about the Other. Yale French Studies, nr 87 [Another Look, Another Woman: Retranslations of French Feminism], 7-19.

Key, M.R. (1975). Male/Female Language. Metuchen, NJ: The Scarecrow Press.

Scott, J.W. (1986). Gender: a useful category of historical analysis. American Historical Review, nr 5(91), 1053-1075.

Sommer, R. (1969). Personal space: The Behavioral Basis of Design. Englewood Cliffs, NJ: Prentice-Hall.

Oksana Kozhemiakina - docent przy Katedrze Filozoficznych i Politycznych Nauk Państwowego Technologicznego Uniwersytetu w Czerkasach. Do sfery naukowych zainteresowań autorki należą: polityczna filozofia, filozofia zaufania, psychologia i filozofia gender, kultura mediów. 
